\title{
The Implementation of Market Service Retribution Policy of Trade and Industry Department of Pekanbaru
}

\author{
Hernimawati, Wasiah Sufi \\ Universitas Lancang Kuning \\ e-mail: hernimawati@unilak.ac.id
}

\begin{abstract}
The market service retribution policy is basically a part of the source of local revenue that is quite necassary which will also determine the level of a region self-development and it can also determine the target of development and the area of development in the future. This study aims to determine the implementation of market service retribution policies in the Department of Trade and Industry of Pekanbaru City along with supporting factors and barriers. The research method used is descriptive method with a qualitative approachment. The theory used is the theory of George C.Edwards III which suggests four indicators that play an important role in achieving successful implementation. The results showed that the implementation of the market service retribution policy in Disperindag Pekanbaru City has shown good results, where policies were implemented in accordance with local regulations that have been made by the Regional Government regarding to The Market Service Retribution. However, lack of human resources as an interpreter or inner worker who is a civil servant because all this time the inner bill is an employee of honorarium, which is worried to commit fraud as well as retribution from the market service and the lack of financial or budgetary resources received due to a lack of awareness retribution in complying with regulations that have been included in the Regional Regulations regarding payment of retribution.
\end{abstract}

Keywords: Implementation, Retribution Policy, PAD

Kebijakan retribusi pelayanan pasar pada dasarnya merupakan bagian dari sumber penerimaan Pendapatan Asli Daerah yang cukup berarti dimana kontribusi pasar akan turut menentukan besarnya tingkat kemandirian suatu daerah, yang juga dapat menentukan arah perkembangan dan pembangunan suatu daerah kedepannya. Penelitian ini bertujuan untuk mengetahui implementasi kebijakan retribusi pelayanan pasar di Dinas Perdagangan dan Perindustrian Kota Pekanbaru beserta faktor pendukung dan penghambatnya. Metode penelitian yang digunakan adalah metode deskriptif dengan pendekatan kualitatif. Teori yang digunakan adalah Teori George C.Edward s III yang mengemukakan empat indikator yang berperan penting dalam pencapaian keberhasilan implementasi. Hasil penelitian menunjukan bahwa implementasi kebijakan retribusi pelayanan pasar di Disperindag Kota Pekanbaru sudah menunjukan hasil yang cukup baik, dimana kebijakan yang dilaksanakan sesuai dengan peraturan daerah yang sudah dibuat oleh Pemerintah Daerah tentang Retribusi Pelayanan Pasar, namun masih kurangnya SDM sebagai juru tagih atau inner yang berstatus PNS dikarenakan selama ini juru tagih atau inner merupakan pegawai honor, yang dikhawatirkan melakukan penyelewengan seperti halnya penggelapan retribusi pelayanan pasar serta Masih sangat minimnya jumlah sumber daya finansial atau anggaran yang diterima dikarenakan kurangnya kesadaran wajib retribusi dalam menaati peraturan yang sudah dicantumkan dalam Peraturan Daerah mengenai pembayaran retribusi.

Kata Kunci : Implementation, Retribution Policy, PAD 


\section{INTRODUCTION}

Regional autonomy defines as the obligation given to the autonomous region for managing and taking care of government affairs and public interests based on the public aspiration to improve the usability and result of governmental administration as the public service and the development implementation based on the regulation.

A region was formed rely on economic ability, region potency, social culture, social politik, the number of population, geographical condition, etc. It is contained in the constitution No. 12, 2008, about local government (it was changed into constitution No. 12, 2008 deals with the changing of constitution No. 31, 2004). It was stated that "regional autonomy is a right, authority, and obligation of the autonomous region for managing and taking care of its government affairs and public interests based on the regulation".

By establishing an autonom to a region, it allows the region to manage and take cares its government affairs for increasing the ability and result of governmental administration towards the public service. For implementing regional autonomy optimally, it needs a high fund. Some fund is allocated by the region itself from the local revenue (PAD). It means that, if the region has a sufficient fund, it is easy for organizing the government affairs. As the result, the community prosperity will be achieved.

Local revenue is an icome sourced from tax as stated in the constitution. Local revenue is all income sourced from local economy, they are local tax, local retribution, local resources, and all legal funds.

Constitution No. 33, 2004, states that funding resources of regional government implementation consist of local revenue, profit sharing fund, general alocation fund, particular allocation fund, local loan, and all legal funds. In this case, local revenue is an icome sourced from tax as stated in the constitution. Local revenue is all income sourced from local economy, they are local tax, local retribution, local resources, and all the legal funds, with aims at allowing the local region to explore the funding and regional autonomy implementation.

The legal mandate of constitution No. 32 and 33, 2004 say that local retribution is one of the local revenue sources for funding the government implementation. Constitution No. 34, 2000, about local tax and local retribution clarify that local retribution is services payment or particular licensing given by the local government for individual interests or agency interests.

The most important regional income resource is local retribution. Retribution defines as all payment from the public who used the local public services. It also can be defined as the dues for the government services given. The dues are economic because the public will not pay if they are not served.

The following table presents the sources of local revenue based on constitution No. 33, 2004.

Table I.1 The Sources of Local Revenue

\begin{tabular}{lll}
\hline No & Pendapatan Asli Daerah & The Sources of local revenue \\
\hline
\end{tabular}

1 Regional tax

P-ISSN 1693-3516 | E-ISSN 2528-7575
Tax form Hotel, Restaurant, entertainment, advertisement, property, etc. 


\begin{tabular}{|c|c|c|}
\hline 2 & Regional Retribution & $\begin{array}{l}\text { Public Service Retribution (Market } \\
\text { Service Retribution, Health Retribution, } \\
\text { Cleanliness Retribution, Sidewalk } \\
\text { Parking Lot, Funeral Retribution, etc) } \\
\text { Business Sevice Retribution (Termint } \\
\text { Retribution, Slaughterhouses Retribution, } \\
\text { Recreation and Sport Area Retribution, } \\
\text { etc) Licensing Service Retribution } \\
\text { (Building Licensing, Aperitif Shop } \\
\text { Licensing, Route Licensing, Fishery } \\
\text { Business Licensing, etc) }\end{array}$ \\
\hline 3 & $\begin{array}{l}\text { Separated Local Property } \\
\text { Management Outcome }\end{array}$ & $\begin{array}{l}\text { Income from the equity capital on local } \\
\text { enterprise, Income from the equity capital } \\
\text { on state enterprise, Income from the } \\
\text { equity capital on individual or a group of } \\
\text { community company. }\end{array}$ \\
\hline 4 & Other Legal Local Revenue & Grant and Emergency Fund Income. \\
\hline
\end{tabular}

Data Source: Trade and Industry Departement of Pekanbaru, 2019

The above table describes that there are a lot of sources for local revenue so the regional government has no reason for not financing its own needs. As the result, regional government is able to stay independent.

Local retribution as a local tax is one of the local revenue that being one of the source for financing the government implementation and local development with aims at improving and equalizing the community welfare.

Local retribution is a potential local revenue source because it has a wider scope than local tax. Adisasmita (2011) states that the development of local retribution is easier than local tax because local retribution's scope is looser than local tax. So that is why the regional government has focus on the effort of local retribution acceptance improvement.

The difference between tax and retribution is described as follows:

1. Remuneration accepted by the taxpayer or community. For the taxpayer, after doing payment of the tax, she/he cannot take the remuneration directly. The all tax will submit at first. Then, it will be used for the public interests. Otherwise, for the people who pay the retribution will take the remuneration directly such as parking charge payment.

2. Taxable object. The taxable objects are income, wealth, company profit, and vehicle. Otherwise, retribution objects are particular people who use the government service such as health service, terminal, and market service.

3. Tax and retribution are not collected by the same institution. Central government or Regional government will organize the tax payment and local government especially Income Office Region (dispenda) will organize the retribution payment.

Trade sector has a crucial role in developing Pekanbaru economical development. It shows that trade sector is able to drive the local economy. The development of a town is determined by the efficiency of spatial management for supporting the economical activities.

The increasing of a regional economy will goes along with the trade activity development in that region and its surrounding. One of the medium is market, either traditional market or modern market. 
Market is a mechanism bringing seller and buyer face to face to make a deal about goods and services. One of the requirements of market is a transaction bertween seller and buyer relates to goods and services, and manpower for other people by money rewards.

Globalization era causes consuming lifestyle changing in completing life necessities. Finaly, consumen will move forward to modern market. Traditional market with the limited facilities makes the consuments' interest decrease to buy the daily necessities there.

So, it will cause a competition between traditional and modern market that influence the seller income. Therefore, the central or regional government role is needed to handle the modern market development and empowering traditional market to be better.

In Pekanbaru city, local retribution is one of local revenue sources which are expected to give a big contribution for the local revenue. So, the local government make effective policies to improve the local revenue retribution continuously.

One of developed local retribution is market retribution. It is one of public services with a potential utilization. It gives a lot of advantages either for the market user or the local government. The advantages of retribution for the market users are for satisfying them in case of supply services, market facilities usage and maintenance such as market yard and stall from the government. The advantage of market retribubtion for local government is as one of the potential local revenue to improve it.

In order to increase the local revenue, market retribution subsector is a part of meaningfull local revenue sources. It means that the market contribution will determines the local government independent and also determines the goal of region improvement and development in the future. Goes along with it, market retribution is needed to explore and expand because it is taken by the government based on the remuneration regulation.

Retribution market management is very important in Pekanbaru. It makes government need to guide the apparatus to collect the tax in discipline, watch and built the community awareness in paying the retribution and looking after the facilities.

The success of market retribution management is based on the ways of retribution collecting system decided by the local government. In the implementation of the system, it shoul be adjusted by the market activities. Retribution collection can be a best system if it is well organized. So, it can give a good service and regulation for the market service users.

The importance of implementation and monitoring system of market retribution management aims at keeping the activities in the market retribution management system runs well. Besides that, this kind of monitoring is aimed to find out the weaknesses faced by the collection system.

The role of local government administrator in implementing the local affairs especially in market retribution organization is an important part of local revenue area. So, all the factors which influence the achievement should be watched carefully. They can be market facilities, officers' discipline, apparatus' capability, traders' awareness, and policies used, because they can affect the market retribution sources.

Because the proportion of retribution donates a big fund for local revenue in Pekanbaru, the government produced Government Regulation of Pekanbaru No. 06, 2012, about Market Service Retribution.

Policies are the series of government reactions which aims to manage the problem faced by the community. These policies also have specific goals oriented to the public interests to solve the problem, satisfy the public needs and demands. Policies contain all the government actions that should be obeyed by the executors and the users.

Policies mechanism which manages the market retribution services lied on the Local Government Regulation of Pekanbaru No. 6, 2012, which is formulated by the Mayor, the head of Trade and Industry Department, the head of sectors of Trade and Industry Department, and the Head of Regional Revenue 
Agency. Then, it is implemented and socialized to the traders in market managed by the Trade and Industry Departement of Pekanbaru.

The role of Trade and Industry Department of Pekanbaru related to Regional Regulation No. 6, 2012, decribes about the main duty in government implementation and services related to trade and industry sectors.

Pekanbaru as the capital city of Riau province establishes Regional Secretariat that leads 23 departments and 5 agencies. One of the services with the complex tasks is Trade and Industry Department.

The main dutyof Trade and Industry Department are managing and collecting the local revenue in market sector, investigating and evaluating the market diciplines and cleanliness, and all related activities based on the Mayor's policies and regulations.

Market defines as one of the economic facilities for cetral community shopping activity in fulfilling daily needs and for traders in doing business. Market may be built by the local government or individual company. Local government authorizes the Trade and Industry Department to manage its own market facilities by accommodating traders' aspirations. This department also assists the Mayor's duty dealing with regional autonomy efforts through market management sectors.

Nowadays, the development of markets in Pekanbaru increased significantly. The following table presents market types in Pekanbaru.

Tabel I.2 Markets in di Pekanbaru

\begin{tabular}{|c|c|c|}
\hline No & Markets in di Pekanbaru & Market Names \\
\hline 1 & Government Markets Managed by Pihak III & $\begin{array}{l}\text { 1. Pasar Bawah } \\
\text { 2. Pasar Sail } \\
\text { 3. Pasar Senapelan }\end{array}$ \\
\hline 2 & Markets Managed by Trade and Industry Dept. & $\begin{array}{l}\text { 1. Pasar Lima Puluh } \\
\text { 2. Pasar Sukaramai } \\
\text { 3. Pasar Labuh Baru } \\
\text { 4. Pasar Cik Puan } \\
\text { 5. Pasar Simpang Baru } \\
\text { 6. Pasar Rumbai } \\
\text { 7. Pasar Higienis Madani }\end{array}$ \\
\hline 3 & $\begin{array}{l}\text { Traditional Markets Managed by Individual } \\
\text { Company }\end{array}$ & $\begin{array}{l}\text { 1. Pasar Dupa } \\
\text { 2. Pasar Arengka } \\
\text { 3. Pasar Tangor } \\
\text { 4. Pasar Sago } \\
\text { 5. Pasar Jondul } \\
\text { 6. Pasar Yos Sudarso } \\
\text { 7. Pasar Palas } \\
\text { 8. Pasar Teleng } \\
\text { 9. Pasar Kartin } \\
\end{array}$ \\
\hline
\end{tabular}

Data Source: Trade and Industry Deaprtment Pekanbaru, 2019

Table 1.2 explain us about the numbers of markets in Pekanbaru. They are Government Markets Managed by third group, Markets Managed by Trade and Industry Department, and Traditional Markets Managed by Individual Company with different condition and location of the markets. 
The existence of markets should be payed full attention by the government. Government awareness is very crucial because the market asset belongs to them and trader just has usage right. Government must protect the market as the effort to develop market continuous durability and empower it as the space for economic activities in order to achieve the community welfare.

Markets managed by the government organized based on the Trade Ministry Regulation, Presiden Regulation, and Local Regulation. This following table presents the numbers of stall and los managed by Trade and Industry Department.

Tabel I.3 Number of Stall and Los in Markets Managed by Trade and Industry Department of Pekanbaru, 2019

\begin{tabular}{clcccccc}
\hline \multirow{2}{*}{ NO } & \multirow{2}{*}{ Market Names } & \multicolumn{3}{c}{ Stall } & \multicolumn{3}{c}{ Los } \\
\cline { 3 - 7 } & & Total & Used & Free & Total & Used & Free \\
\hline 1 & Lima Puluh & 102 & 90 & 12 & 170 & 107 & 63 \\
\hline 2 & Sukaramai & 77 & 20 & 57 & - & - & - \\
\hline 3 & Labuh Baru & 64 & 25 & 39 & 237 & 65 & 172 \\
\hline 4 & Cik Puan & 570 & 149 & 421 & 237 & 82 & 155 \\
\hline 5 & Simpang Baru & 64 & 32 & 32 & 32 & 32 & 0 \\
\hline 6 & Rumbai & 210 & 118 & 92 & 245 & 240 & 5 \\
\hline 7 & Higienis Madani & 10 & 5 & 5 & 140 & 80 & 60
\end{tabular}

Data Source: Trade and Industry Department of Pekanbaru, 2019

The table 1.3 above shows the numbers of stall and los managed by Trade and Industry Department of Pekanbaru. The big number of stalls used is in Cik Puan Market which are 570 while a few stall used is in Higienis Mandani Market which are 10. The big number los used is in Rumbai Market which are 245 and the little one is in Simpang Baru Market which is 32.

So far, there are many traders who sell the goods in the roadside. They make the Trade and Industry Department hard to establish the discipline in the market. So, there are a lot of free stall found in the market. It finaly influences the market retribution service collected by Trade and Industry Department.

Furthermore, it is very expected that the guidance implemented in Pekanbaru markets runs well. The traders will be better in the future and the government can train roadside traders to use the stall and los in the market.

Retribution is local revenue as the sevice and particular license payment specifically given and provided by the local government for individual and agencies interests. This local revenue will be used for the local government development.

Market servise retribution is part of public service retributions. This service income comes from public service provisions and public administration. Market service retribution is set based on the following criteria:

1. The spacious coverage area for business and trading activity.

2. Building type for business and trading activity.

3. Expiration date for business and trading activity. market.

The following table presents the market retribution price list and cleanliness services in each 
Tabel I.4 Market Retribution Price List Based on Local Regulation No. 6, 2012

\begin{tabular}{|c|c|c|c|c|}
\hline \multirow{2}{*}{ No } & \multirow{2}{*}{$\begin{array}{c}\text { Retribution } \\
\text { Object }\end{array}$} & \multicolumn{3}{|c|}{ Total Tagihan } \\
\hline & & Stall & Los & Roadside \\
\hline 1 & Lima Puluh & 90.000/month & 78.750/month & 2.000/day \\
\hline 2 & Sukaramai & $76.500 /$ month & 2.000/day & 2.000/day \\
\hline 3 & Labuh Baru & $90.000 /$ month & 2000/day & 2.000/day \\
\hline 4 & Cik Puan & $46.500 /$ month & 2.000/day & $2.000 /$ day \\
\hline 5 & Simpang Baru & $90.000 /$ month & 2.000/day & 2.000/day \\
\hline 6 & Rumbai & $\begin{array}{c}103.500 / \text { mont } \\
\mathrm{h}\end{array}$ & 2000/day & 2.000/day \\
\hline 7 & $\begin{array}{l}\text { Teratai } \\
\text { Higienis }\end{array}$ & $90.000 /$ month & 2.000/day & 2.000/day \\
\hline
\end{tabular}

Data Source: Trade and Industry Department of Pekanbaru, 2019

From the table above, it can be known that market service retribution price list is different each others. It will increase the local revenue for the local government. It is also expected that the number of traders will improve. The table aslo shows that the biggest price list retribution is found in Rumbai Market. In conclusion, the biggest retribution for local revenue is from Rumbai Market.

Everey market has stall and los for traders. The following table shows us the target and retribution realization of market service managed by the Trade and Industry Department.

Tabel I.5 Target and Market Service Retribution Realization from 2015 to 2018

\begin{tabular}{ccccc}
\hline No & Year & Target & Realiation & $\begin{array}{c}\text { Realization } \\
\text { Perscentage } \\
(\%)\end{array}$ \\
\hline 1 & 2015 & 800.010 .000 & 756.505 .500 & 94,56 \\
\hline 2 & 2016 & 809.235 .000 & 784.873 .250 & 96,99 \\
\hline 3 & 2017 & 894.978 .000 & 479.369 .000 & 53,56 \\
\hline 4 & 2018 & 1.549 .026 .000 & 631.008 .500 & 40,74 \\
\hline
\end{tabular}

Data Source: Trade and Industry Department of Pekanbaru, 2019

Table 1.5 describes the total percentage of market service achievement of Trade and Industry of Pekanbaru in the last four years faced the reduction. In 2015, the market service retribution achievement is about $94.56 \%$ with the target 800.010 .000 . In fact, the realization is only achieved 756.505.500. In 2018 , there was a reduction happened significantly in $40.74 \%$ with the target 1.549 .026 .000 and only achieved 631.008.500. It caused by the potency of stall and los does not run well. There are a lot of traders have no awareness to pa the market retribution.

Tabel I.6 Market Service Retribution Realization from 2015 to 2018

\begin{tabular}{clcccc}
\hline \multirow{2}{*}{ No } & Market & \multicolumn{4}{c}{ Realization } \\
\cline { 3 - 5 } & Retribution Object & $\mathbf{2 0 1 5}$ & $\mathbf{2 0 1 6}$ & $\mathbf{2 0 1 7}$ & $\mathbf{2 0 1 8}$ \\
\hline \multirow{2}{*}{1} & Lima Puluh & 127.757 .000 & 156.361 .750 & 88.876 .500 & 113.239 .500 \\
\hline
\end{tabular}




\begin{tabular}{clcccc}
\hline 2 & Sukaramai & 76.513 .000 & 78.236 .000 & 59.868 .000 & 83.868 .000 \\
\hline 3 & Labuh Baru & 76.519 .000 & 83.263 .500 & 76.946 .000 & 96.933 .250 \\
\hline 4 & Cik Puan & 139.191 .500 & 133.398 .250 & 58.766 .000 & 84.930 .500 \\
\hline 5 & Simpang Baru & 89.878 .500 & 96.523 .000 & 69.525 .500 & 93.815 .750 \\
\hline 6 & Rumbai & 246.646 .500 & 225.090 .750 & 97.520 .000 & 158.221 .500 \\
\hline 7 & Teratai Higienis & - & - & 27.867 .000 & - \\
\hline
\end{tabular}

Data Source: Trade and Industry Department of Pekanbaru, 2019

The above table shows that Rumbai Market has the biggest market service retribution managed by the Trade and Industry Department of Pekanbaru. It is confirmed that the daily shopping activity is very active in Rumbai Market eventhought the total of market service retribution decreased from 2015 to 2018. Otherwise, the lowest market service retribution managed by the Trade and Industry Department of Pekanbaru is given by Teratau Higienis Madani Market. It is caused by the trader chosing to sell the goods in the roadside of Kodim Market. It also easier the buyers to buy the goods they need because there is no distance. So, it causes the decrease of market service retribution year by year. In another case, the punishment for the traders who do not obey the regulation is not apllied yet.

So that is why there should be ways done by the Ttrade and Industry Department to solve the problem. First is socialization. Government should socialize the traders to use the stall and los provided by the Tade and Industry Department of Pekanbaru. Second, there should be an effort to ease the traders such as by deciding the affordable stall rent cost for the stall and los. Besides that, the government should provide adequate facilities for them.

Market service retribution system managed by Trade and Industry Department of Pekanbaru is collected directly by an inner worker. Every local technical management unit has an inner worker. Stall retribution is collected per month, los and roadside retributions are collected per day.

Retribution collected by the inner worker is given to the recipient treasurer of Trade and Industry Department of Pekanbaru. For the daily retribution such as los and roadside retribution must be given at the same day to avoid the trouble as well as fraud.

The following table inform us the data of inner worker in every market local technical management unit managed by the Trade and Industry of Pekanbaru.

Tabel I.7 Market Inner Workers Biodata

\begin{tabular}{|c|c|c|}
\hline No & Market Name & Inner Worker Biodata \\
\hline 1 & Lima Puluh & $\begin{array}{ll}\text { Name } & : \text { Ismail Nasri } \\
\text { Age } & : 41 \text { Tahun } \\
\text { Length of working } & : 4 \text { Tahun }\end{array}$ \\
\hline 2 & Sukaramai & $\begin{array}{ll}\text { Name } & : \text { Toto Setiadi } \\
\text { Age } & : \text { 39 Tahun } \\
\text { Length of working } & : 1 \text { Tahun }\end{array}$ \\
\hline 3 & Labuh Baru & $\begin{array}{ll}\text { Name } & : \text { Sayuti } \\
\text { Age } & : 45 \text { Tahun } \\
\text { Length of working } & : 3 \text { Tahun } \\
\end{array}$ \\
\hline 4 & Cik Puan & $\begin{array}{ll}\text { Name } & : \text { Ramzal } \\
\text { Age } & : 40 \text { Tahun } \\
\text { Length of working } & : \text { 2 Tahun }\end{array}$ \\
\hline
\end{tabular}




\begin{tabular}{ccll}
\hline \multirow{3}{*}{5} & \multirow{2}{*}{ Simpang Baru } & Name & : Indra (Pak Datuk) \\
& & Age & $:$ 49 Tahun \\
& Length of working & $: 7$ Tahun \\
\hline \multirow{3}{*}{6} & Rame & $:$ Syamzir Tambunan \\
& & Age & $: 46$ Tahun \\
& & Length of working & $: 7$ Tahun \\
\hline \multirow{3}{*}{7} & Higienis Madani & Name & $:$ Erwan Nababan \\
& & Age & $:$ 42 Tahun \\
& & Length of working & $: 1$ Tahun
\end{tabular}

Data Source: Trade and Industry Department of Pekanbaru, 2019

Table 1.7 describes that inner workers have the effective ages to collect the market service retribution. Unfortunately, the length of workings is different. There are two inner workers have long time in working and the others have short time in working.

The reason why the researcher investigated the Implementation of Market Service Retribution Policy in Trade and Industry Department of Pekanbaru is to find out how the implementation of Market Service Retribution run is because this kind of retribution is one of the biggest sources of local revenue.

Therefore, regional government of Pekanbaru through Trade and Industry Department is expected to improve the effective policy about local retribution management to increase the local retribution income to support the local revenue based on the Local Regulation of Pekanbaru No. 6, 2012 about market service retribution.

Trade and Industry Department defines as one of the departments in government with the duty to achieve the regional autonomy in market management. The important implementation defines as actions or management or implementation of well organized plans. Policy implementation defines as actions done by individual or official or groups of government or community toward the particular goals achievement.

\section{METHOD}

The method of the research was qualitative with triangulation data analysis from interview script, observation, and documentation. After collecting the data, the researcher grouped the data based on the types and presented them in such kind of description and explanation. After that, the researcher analyzed the data by using descriptive analysis. It means that the data analyzed by describing them.

\section{FINDING AND DISCUSSION}

Market is a medium for economic activity. It is the central of shopping needed by the community in fulfilling their necessity. It is used by the traders to do business interest. Market can be provided by the local government or private company. Government will manage its own market facility through Trade and Industry Department. This department will accommodate the traders' aspiration. Market as a part of sectors in local government supports the Mayor to achieve the regional autonomy. So, the Trade and Industry Department is expected to be able to manage the market effectively and efficiently.

Serious management and attention given from the government of Pekanbaru in managing market influenced the market service retribution. Retribution is a local tax as service and particular licencing 
provided by the local government for agency interests. Retribution defines as local revenue that will be used for local government development.

Market revitalization in order to improve the market needs a high cost. Besies that, market development is assumed limiting the old traders business because they have to pay bigger retribution. As the result, the welfare cannot be reach. Almost of the old traders must go out because they cannot pay the retribution. Furthermore, this policy needs to evaluate in order to get the maximal goal because market is one of the community economical foundations. If the development is not maximal, it will affect the welfare of surrounding community.

Serious management and attention paid by the government in managing the market influenced market retribution. With the bigger attention, it is possible that markets in Pekanbaru would donate huge local revenue related to retribution price list.

Communication determines the success of public policy implementation achievement. The effective implementation will occurs if the decision makers know what they need to do. Besides that, the policies communicated should be appropriate, accurate, and consistent. Communication is needed. So, the decision makers and implementers are more consistent in implement the policies applied in community.

In this case, communication refers to every policy that can be implemented well if there is an effective communication between policy executor and target community. The aim and target of the policy can be socialized to avoid fraud.

The result of interview shows that the communication went along with the goal set. Then, it becomes the duty of the department personnel in market service retribution in the seven markets managed by the Trade and Industry Department of Pekanbaru. Eeventhough a policy has been communicated clearly and consistently, the implementation cannot run effectively if the implementor has no capability to do it.

The capability is human resources with the educational level, implementor competence in policy implementation, and financial capability or funding needed to improve the personnel competence in completing the duty.

Capability is the important factor in policy implementation so it will run effectively. Without capability, policy is meaningless and useless. It means that human resource is one of the factors supporting the implementation of duties given. Human resource influences the finishing step of the duty. The personnel's competency will supports the implementation of the duties. Unfortunately, today's human resource in implementing the market service retribution does not run yet maximally.

From the data presentation can be known that the personnel of the policy implementation is good enough. Personnel's role is important and acceptable by the traders, there was no problem found related to the policy implementation. However, the quality of human resource as inner worker in implementing the market service retribution is lack. So, it is worried to commit fraud as well as retribution from the market service.

Then, budget supporting the implementation of policy is one of the supporting factors of organization implementation. If there is no budget, it will be no program handled.

Disposition refers to the characters owned by the implementor or inner workers such as commitment, honesty, and democratic. If the implementor has good character, the policy will be implemented well. Otherwise, if the implementor has different point of view with the policy maker, the implementation process will run uneffectively.

Commitment of the policy executor will support the implementation of the policy. A policy cannot be run and achieve the goal if the executors have no commitment to do the duty and responsibility.

Honesty is an absolute attitude that must be had by an impelementer. With no honesty in implementing the policy, the trust from policy maker and community will lost. It means that honesty should apply in implementing the policy so the goal will be achieved. 
From the result of interview, it can be concluded that inner workers who collected the market service restribution has the commitment in doing job based on his authority. Besides that, the inner workers must have honesty to implement the policy of market retribution in Trade and Industry Department of Pekanbaru especialy about market retribution deposit responsibility to local revenue.

The structure organization which runs the implementation of policy has an important role. One of the important aspecst from each organization is standar operating procedure (SOP). It will be a guide for every implementor in doing the actions.

From the result of interview, it can be noted that every personnel has been socialized about the main job and function so there will be no double job in implementing the market service retribution policy.

The description of organization applied the policy has an affect to the process. Personnel job descriptions should be run well and related to the structure of organization.

Based on four indicators of Market Service Retribution Implementation of Trade and Industry Department of Pekanbaru, it can be concluded that indicator resource does not achieve the goal yet. It is also supported by other indicators; communication, disposition, and structure of bureaucracy.

\section{The Obstacles of Market Service Retribution Implementation of Trade and Industry Department of Pekanbaru}

Obstacles found related to Market Service Retribution Implementation of Trade and Industry Department of Pekanbaru are:

a. The lack of human resource quality as the inner workers in depositing the retribution. It is caused by the status as honorarium employee which is worried to commit fraud as well as retribution from the market service, and they have no worry of firring.

b. The number of market service retribution is still low so operational budget in every market is lack. As the solution, it is taken form local budget income which allocated for health and education, etc.

\section{CONCLUSION}

Based on finding discussed, there are conclusions noted:

a. The impelementation of effective communication run in line with guide and the socialization given. But, the target set does not run maximaly because the lack of traders' awareness to pay the retribution.

b. Both human resource and financial resource do not run well because the status of inner as honorarium and the retribution target is not achieved yet.

c. Disposition, an impelementor must have nice characters such as commitment, honesty, and democratic, so the implementation of policy will be achieved.

d. Structure of bureaucracy. It contains of 2 sub-indicators, mechanism of job distribution and job description of the structure of organization applied well.

\section{SUGGESTION}

The obstacle of Market Service Retribution Implementation of Trade and Industry of Pekanbaru is the lack of resources. They are human resources and financial resources. Based on four indicators of Market Service Retribution Implementation of Trade and Industry Department of Pekanbaru, it can be concluded that indicator resource does not achieve the goal yet. It is also supported by other indicators; communication, disposition, and structure of bureaucracy. 


\section{BIBLIOGRAPHY}

[1]. Abidin, Said Zainal, 2012, Kebijakan Publik, Salemba Humanika, Jakarta.

[2]. Alden, Dkk, 2010, Jurnal Implementasi Kebijakan Pengelolaan Retribusi Pasar dalam Menunjang Pendapatan Asli Daerah di Kabupaten Pulau Morotai, Yogyakarta.

[3]. Badrudin, 2013, Dasar-Dasar Manajemen, Alfabeta, Bandung.

[4]. eka, eka. (2019). Implementasi Undang-Undang Nomor 6 Tahun 2014 Kepala Desa Dalam Menjalankan Tugas Di Desa Aur Kuning Kecamatan Kampar Kiri Hulu Kabupaten Kampar. Jurnal Niara, 12(1), 62- 68. https://doi.org/10.31849/nia.v12i1.2635

[5]. Humaidi, Muchlis, 2014, Kebijakan Publik Proses Analisis dan Partisipasi, Ghalia Indonesia, Bandung.

[6]. Kencana, Syafiie Inu, 2012, Sistem Administrasi Negara Republik Indonesia, Bumi Aksara, Jakarta.

[7]. Pasolong, Harbani, 2012, Metode Penelitian Administrasi Publik, Alfabeta, Bandung.

[8]. Pasolong, Harbani,, 2014, Teori Administrasi Publik, Alfabeta, Bandung.

[9]. Pasolong, Harbani,, 2014, Aspek-Aspek Ilmu Administrasi, Ghalia Indonesia, Jakarta.

[10]. Purwanto, Dkk, 2010, Implementasi Kebijakan Publik, Gava Media, Yogyakarta.

[11]. Siswanto, HB, 2012, Pengantar Manajemen, PT Bumi Aksara, Jakarta.

[12]. Subarsono, AG, 2011, Analisis Kebijakan Publik, Pustaka Pelajar, Yogyakarta.

[13]. Sugiyono, 2012, Metode Penelitian Administrasi, Alfabeta, Bandung.

[14]. Sutarto, 2011, Dasar-dasar Organisasi, Gadjah Mada University Press, Yogyakarta.

[15]. Saputra, T., Marlinda, P., \& Sufi, W. Implementasi Kebijakan Inovasi Pelayanan Publik Di Puskesmas Jaya Mukti Dalam Meningkatkan Kepuasan Masyarakat. Jurnal Niara, 11(2.2019), 177188.

[16]. Dailiati, S., \& Saputra, T. (2018, May). Rising Pendapatan Asli Daerah (PAD) in Pekanbaru: Billboard Planning Policy Tax. In IOP Conference Series: Earth and Environmental Science (Vol. 156, No. 1, p. 012032). IOP Publishing.

[17]. Thoha, Mifta, 2010, Perilaku Organisasi, Rajawali, Jakarta.

[18]. Torang, Syamsyir, 2013, Organisasi dan Manajemen, Alfabeta, Bandung.

[19]. Umam, Khaerul, 2012, Manajemen Organisasi, Pustaka Setia, Bandung. 
[20]. Usman, Kumorotomo Wahyudi, 2014, Etika Administrasi Negara, Rajawali Pers, Jakarta.

[21]. Peraturan Daerah No 8 Tahun 2008 Tentang Pembentukan Susunan Organisasi Kedudukan dan Tugas Pokok Dinas-Dinas di Lingkungan Pemerintah KotaPekanbaru.

[22]. Peraturan Daerah Kota Pekanbaru Nomor 9 Tahun 2016 tentang Pembentukan dan Susunan Perangkat Daerah Kota Pekanbaru.

[23]. Peraturan Walikota Pekanbaru No 114 Tahun 2016 Tentang Kedudukan, Susunan Organisasi, Tugas dan Fungsi serta Tata Kerja Dinas Perdagangan dan Perindustrian Kota Pekanbaru.

[24]. Peraturan Daerah Kota Pekanbaru No. 06 Tahun 2012 Tentang Retribusi Pelayanan Pasar.I

[25]. Undang-Undang No. 23 Tahun 2014 Tentang Pemerintahan Daerah. 